\title{
Juízo, ser e reflexão: Hölderlin leitor de Fichte
}

João Geraldo Martins da Cunha

\section{(2) OpenEdition}

\section{Journals}

Edição electrónica

URL: http://journals.openedition.org/ref/444

DOI: $10.4000 /$ ref.444

ISSN: 2258-014X

\section{Editora}

EuroPhilosophie Editions

Refêrencia eletrónica

João Geraldo Martins da Cunha, « Juízo, ser e reflexão: Hölderlin leitor de Fichte », Revista de Estud(i)os sobre Fichte [Online], 6 | 2013, posto online no dia 03 junho 2013, consultado o 08 setembro 2020. URL : http://journals.openedition.org/ref/444 ; DOI : https://doi.org/10.4000/ref.444

Este documento foi criado de forma automática no dia 8 setembro 2020

(c) EuroPhilosophie 


\title{
Juízo, ser e reflexão: Hölderlin leitor de Fichte
}

\author{
João Geraldo Martins da Cunha
}

I

1 Embora os irmãos Schlegel tenham começado a estruturar as ideias básicas do movimento romântico alemão inspirados pela Grundlage-1794-5 (GWL) de Fichte, esta proximidade, como se sabe, nunca foi muito longe. $\mathrm{E}$ isso tanto porque a reflexão estética não foi uma preocupação central de Fichte, quanto porque, e a bem da verdade, a arte não poderia ocupar qualquer lugar privilegiado na estruturação sistemática da Wissenschaftslehre. O movimento de autofundação dos três princípios da GWL parece apontar, quase que exclusivamente, para uma bifurcação entre saber teórico e saber prático, em vista da qual a arte poderia ocupar um lugar apenas subalterno ${ }^{1}$. Na medida em que a arte poderia ser vista apenas como uma "ciência aplicada" no interior do sistema, possivelmente foi a pretensão comum de superar as dicotomias kantianas (sensibilidade e entendimento, natureza e liberdade, intuição e conceito etc.) a razão mais forte para a aproximação que o movimento romântico procurou, pelo menos em seus começos, com a filosofia de Fichte.

2 Sendo assim, o que parece restar de comum aos dois lados, tão divergentes quanto ao problema elementar acerca do papel a ser desempenhado pela arte, talvez seja sua motivação em procurar a "unidade" para as cisões kantianas. Mas, se este flerte entre a filosofia de Fichte e o movimento romântico foi tão passageiro, penso que a razão de sua ruptura pode ser encontrada no lugar mesmo de sua motivação. Assim, o tema da "unidade" parece ter sido uma das chaves centrais tanto para sua quase convergência, quanto sua completa divergência e ruptura entre o romantismo e a filosofia de Fichte. Certamente o tratamento desse tema é, por um lado, tão multifacetado quanto o é o próprio movimento romântico alemão e, por outro lado, está disperso ao longo dos mais variados aspectos da filosofia de Fichte. Desse modo, neste trabalho, gostaria de explorar um dos aspectos envolvidos nesta questão a partir de uma perspectiva bem 
definida e específica. Embora não possa recuperar esta discussão in extenso, penso que seja possível, porém, reconstruir: (1) ainda que em seus contornos mais gerais, a compreensão do juízo nos termos apresentados pela GWL; e (2) a crítica ao projeto de Fichte esboçada num fragmento de Hölderlin - que, embora não seja exatamente um "romântico", assume uma posição, a meu ver, bastante emblemática relativamente ao diálogo de Fichte com os românticos strictu sensu -, conhecido como "Juízo e Ser".

Basicamente, contra a doutrina de Fichte - que pode ser lida como uma inflexão radical no primado prático kantiano de uma concordância (Übereinstimmung) prática projetada para o futuro, para um telos -, Hölderlin sustenta a ideia de uma unidade (Einigkeit) como horizonte prévio da existência humana, cujo acesso haveria de ser uma forma de "reflexão" (na arte) que deve prescindir das oposições instauradas no e pelo "juízo". Embora a posição de Hölderlin mantenha bastante autonomia frente àquela dos românticos, creio que este percurso pode mostrar que é por razões de princípio que Fichte se afasta do movimento romântico, porquanto uma espécie de racionalismo de fundo anima sua recusa tanto da ideia de um "ser puro e simples", como algo que estivesse "antes" e "fora" do juízo (nos termos de Hölderlin), quanto, e pela mesma razão, de qualquer lugar privilegiado que a arte pudesse ocupar no sistema do saber do qual a Wissenschafstlehre deve ser a exposição. Este trabalho pretende contribuir de maneira direta apenas para o esclarecimento do primeiro aspecto.

\section{II}

Começo, pois, reconstruindo a noção de juízo que aparece no §3 dela GWL. Ali, Fichte apresenta de maneira original a noção de juízo tético para elucidar a natureza fundamental do Grundsatz que deve fundar o sistema do saber. ${ }^{3}$ A elucidação acerca da noção do juízo tético, por sua vez, é apresentada a partir da distinção entre "juízos sintéticos" e "juízos antitéticos". Vejamos como Fichte apresenta sua compreensão do juízo na Grundlage mediante uma recapitulação das ideias básicas contidas nesta oposição entre "juízo sintético" e "juízo antitético". Primeiramente, convém lembrar que estas análises decorrem de um recorte da "forma lógica" do terceiro princípio. Fichte explica sua compreensão do "princípio de razão" nos seguintes termos:

Se se faz abstração do conteúdo determinado, o eu e o não-eu, tomando-se a mera forma da unificação de opostos pelo conceito de divisibilidade [blosse Form der Vereiningung Entgegengesetzer durch den Begrif der Teilbarkeit], então temos a proposição lógica até agora determinada princípio de razão. ${ }^{4}$

Certamente, não é sem interesse analisar esta interpretação bastante peculiar do "princípio de razão" operada por Fichte ${ }^{5}$, não obstante, para nossos propósitos aqui, interessa-nos apenas indicar que suas análises da "forma lógica" do juízo decorrem desta assunção relativa ao "princípio de razão". Em outras palavras, a compreensão "lógica" do juízo, ou de sua "forma lógica" decorre de uma "abstração" do conteúdo do terceiro princípio; "abstração" que permite a formulação do princípio de razão. 0 que é significativo uma vez que, nessa medida, Fichte pretende fundar "as regras lógicas" de funcionamento dos juízos a partir do terceiro princípio ${ }^{6}$. Vejamos, então, como ele opera este procedimento de "abstração".

6 Suponhamos, tendo em vista uma intrincada argumentação que não poderia ser recuperada aqui ${ }^{7}$, que no juízo duas coisas são identificadas (juízos afirmativos) ou opostas (juízos negativos) do seguinte modo: todo oposto é igual a seu oposto mediante 
um índice (Merkmal) $\mathrm{X}$, e todo igual é oposto a seu igual mediante um índice X; no primeiro caso este $\mathrm{X}$ se chama "razão de referência" (Beziehungsgrund), no segundo, "razão de distinção" (Unterscheidungsgrund). Além disso, todo juízo bem fundado tem apenas uma razão de referência e uma razão de distinção, sob pena de termos vários juízos em vez de um. Acrescente-se que "a ação de procurar pela comparação o índice em que são opostos chama-se método antitético", bem como aquela de "procurar nos opostos o índice em que são iguais" chama-se método sintético; pelo primeiro chegamos a juízos negativos, pelos segundos, a juizos afirmativos. Sendo assim, há uma relação de dependência recíproca entre antítese e síntese, tanto porque a antítese (i.e., procurar nos iguais o índice oposto) pressupõe o fato de que estes iguais "não seriam iguais se não tivessem sido igualados por uma ação sintética", quanto porque a síntese (i.e., procurar nos opostos o índice de sua igualdade) pressupõe opostos que "não seriam opostos se não tivessem sido opostos por uma ação [antitética] do eu". ${ }^{8}$ Assim, análise e síntese são aspectos distintos do funcionamento do entendimento: na antítese se faz abstração daquela ação sintética do eu e na síntese se abstrai daquela ação de oposição do eu, para com isso se chegar, no primeiro caso, à "razão de distinção" e, no segundo, à "razão de referência".

7 Uma vez que a razão de referência indica o gênero e a razão de distinção a diferença específica, rosas e azaléias, por exemplo, são igualadas no gênero flores e opostas a partir de uma possível diferença específica, segundo um juízo antitético determinado; de tal forma que quando são igualadas no gênero se faz abstração de todos os outros índices que serviriam de fundamento para juízos antitéticos possíveis acerca delas.

8 Do ponto de vista das implicações mais gerais, esta análise do funcionamento dos juízos, e de sua distinção, implica uma compreensão bastante peculiar do saber humano como um sistema. Em outras palavras, estas análises revelam que o saber humano, para Fichte, deve ser pensado como um sistema em cadeia, hierarquizado em sínteses cada vez mais "gerais" e "compreensivas" (allgemeinnern, umfassendern): saindo da unidade absoluta referida ao eu, passando pelo eu da reflexão transcendental, e pelo eu da "divisibilidade" (ele é limitado "para poder ser igualado ao não-eu"), ${ }^{9}$ até sua dispersão em sínteses cada vez mais mediadas em direção "ao domínio da parte prática". ${ }^{10}$

Importa destacar que, no interior da cadeia que constitui o sistema do saber humano, temos sínteses que são opostas entre si e igualadas, "compreendidas", nas sínteses superiores, mas o mesmo não vale para a síntese suprema. Exatamente porque é supremo, não pode haver nada mais compreensivo e fundamental do que o eu "pura e simplesmente posto" (schlechthin Gesetzten). Ao ser igualado e oposto a um não-eu, ele não é referido a uma síntese superior que os contém, mas a um conceito inferior, na oposição entre eu e não-eu, por uma "limitação recíproca" ("sie werden sich gegenseitig einschränken"), ${ }_{11}$ ambos estão postos pelo eu como sujeito absoluto ilimitado. Por isso, mais uma vez, o juízo deste sujeito está fora da jurisdição do princípio de razão e não é nem afirmativo nem negativo, nem sintético nem antitético, mas, tão somente "tético" (thetisches Urteil).

Desta compreensão do funcionamento lógico do juízo por meio da distinção entre juízos afirmativos e negativos, pensados como juízos sintéticos e juízos antitéticos, decorre, segundo Fichte, uma limitação da validade do princípio de razão (Satz des Grundes) àquilo que, em nossa consciência, é igualado ou oposto, de tal sorte que um juízo acerca daquilo que não pode ser nem "igualado" nem "oposto" está fora da jurisdição do princípio de razão. Disso tudo, Fichte conclui que um juízo desta natureza não seria 
"fundado", mas constituiria o fundamento de todos os juízos, tecnicamente falando, um juízo tético cujo conteúdo seria o "eu absoluto". ${ }^{12}$ Tentemos, a partir de um exemplo, esclarecer a comprensão do funcionamento do juízo nos termos fichtianos de "síntese" e "antítese".

11 Vemos, pois, como Fichte pretende explicar, talvez possamos dizer, fundar "transcendentalmente"13, as regras lógicas básicas em operação nos juízos mediante as noções de "limitação", "igualdade" e "oposição". Em outras palavras, se os juízos, ao final das contas, equacionam o que a Lógica de Kant entendia como "compreensão" e "extensão" dos conceitos ${ }^{14}$, é porque estas "operações lógicas" estão fundadas no ato originário do eu ao se pôr como "limitado e divisível" na oposição entre eu e não-eu:

As ações lógicas, que se fundam sobre aquelas ações originárias e propriamente não vão além de determinações particulares das mesmas, não serão possíveis uma sem a outra ${ }^{15}$.

Nessa medida, a lógica serve de "fio condutor" para as explicações fichtianas dos princípios da Grundlage, mas, por outro lado, está, ao mesmo tempo, fundada nas ações originárias que, transcendentalmente, condicionam a consciência enquanto tal. ${ }^{16}$

Fichte pretende ainda fazer esta tripartição dos juízos em sintéticos, antitéticos e téticos corresponder aos três momentos do título da quantidade dos juízos tal como expresso na tábua das formas lógicas do juízo na $\mathrm{KrV}$ de Kant. Uma vez que os dois primeiros momentos do título da quantidade - juízos afirmativos e juízos negativos devem corresponder aos sintéticos e aos antitéticos, o juízo tético apresenta de maneira mais adequada uma explicação para a noção kantiana de juízos infinitos - para os quais, segundo Fichte, Kant não teria conseguido oferecer uma explicação satisfatória ${ }^{17}$. Tendo em vista esta aproximação, proposta por Fichte, entre as análises do terceiro princípio da Grundlage e a "forma lógica" dos juízos como uma argumentação que teria levado mais longe a dedução kantiana das categorias, podemos compreender sua alegação de que, com isso temos a resposta, de "maneira geral e satisfatória", para a célebre questão "como são possíveis juízos sintéticos a priori?" ${ }^{18}$. Numa palavra, se a primeira Crítica funda os juízos sintéticos a priori em intuições e conceitos puros, Fichte parece remontar destas condições transcendentais para sua origem genética nos três atos originários (posição, oposição, limitação recíproca ou divisibilidade), notadamente, mostrando a fundação das sínteses judicativas no terceiro princípio. ${ }^{19}$

o problema é que, na condição de juízo, segundo a "forma lógica" dos juízos apresentada por Fichte, um juízo sempre implica um terceiro termo como fundamento da relação entre sujeito e predicado (seja uma "razão de referência", seja uma "razão de distinção"). Como, por outro lado, na condição de expressão da síntese suprema, um juízo tético não pode ser igualado nem oposto, Fichte recorre à noção de "tarefa de um fundamento" (Aufgabe für einen Grund) para poder explicá-lo. Neste sentido, apenas a tarefa (infinita) de aproximação da identidade entre eu e não-eu, como realização prático-moral, poderia operar "índice" da identidade para a proposição "Eu sou eu".

Embora o juízo tético por excelência seja o "eu sou", "em que nada é dito do eu mas sim é deixado vazio o lugar do predicado para a determinação possível do eu ao infinito", ${ }^{20}$ diversos outros, mesmo que não tenham o eu como sujeito lógico, mas que estejam submetidos "ao pôr absoluto do eu", também podem ser considerados desta espécie. Assim, por exemplo, rosas e azaléias igualadas e opostas em juízos antitéticos e sintéticos, também podem ser postas no juízo tético segundo o qual se afirma delas que são belas. Do ponto de vista formal, este juízo enuncia que elas contêm o índice que 
também está contido no ideal do belo; ocorre, porém, que, para além da comparação lógica, i.e., transcendental, não é possível comparar esse índice com o ideal, de tal sorte que, afirma Fichte, meu espírito tem por "tarefa", "proveniente de seu pôr absoluto", encontrá-lo; tarefa a ser solucionada somente por uma aproximação ao infinito. Como se vê, à luz desta consideração da forma lógica do juízo, Fichte explicita o sentido do terceiro princípio da Grundlage, assumindo que a "unidade", para retomar minhas considerações iniciais acerca da relação entre sua filosofia e o movimento romântico, só pode ser pensada como um telos projetado na história como realização prática do homem.

\section{III}

Explorando a proximidade e, ao mesmo tempo, a crítica de Hölderlin ao idealismo de Fichte, Jean-François Courtine comenta um fragmento do poeta suábio cujo tema é a relação entre juízo e $\operatorname{ser}^{21}$. Curiosamente, de um lado da folha lemos sobre o ser e do outro sobre o juízo e não temos como decidir rigorosamente qual é a ordem pretendida pelo autor. Segundo a interpretação do próprio Courtine, devemos começar pelo Sein, uma vez que o argumento central de Hölderlin contra Fichte é exatamente que o ser é sempre pressuposto pelo juízo ${ }^{22}$.

17 Neste fragmento, Hölderlin afirma, expressis verbis, que o "ser puro e simples" (Sein schlechthin) só pode ser acessado pela intuição intelectual, porquanto a mediação judicativa instaura uma cisão que apenas "em parte" é reunião. Este jogo entre o âmbito do juízo, de um lado, e aquele da intuição intelectual de outro, pelo qual Hölderlin apresenta o Sein é emblemático para o idealismo de Fichte (bem como para as respectivas rupturas entre Fichte, Schelling e Hegel). 0 que o poeta faz é retomar uma antiga lição aristotélica segundo a qual o juízo é a operação de diaíresis e syntesis que apresenta ou manifesta "algo como algo" (ti kata tinós) ${ }^{23}$. Mas a contraparte desta lição, talvez sem maiores conseqüências no âmbito da filosofia airstotlética ${ }^{24}$, é apontar o limite intransponível do juízo que só pode ligar pela dissociação, a saber, vinculando duas instâncias como separadas.

18 Assim, a estrutura proposicional do juízo, sujeito e predicado, já ensinada por Aristóteles, pode ter uma conseqüência decisiva do ponto de vista das pretensões "transcendentais" da Wissenschafstlehre, pelo menos aos olhos de Hölderlin. Recuperando a origem etimológica de juízo (Ur-teil), o poeta indica a "cisão" que necessariamente é instaurada pelo juízo. Assim, apenas parcialmente é que o juízo (cuja forma lógica aqui considerada é "S é P") reúne ou "unifica", pois, na verdade, o juízo vincula sujeito e predicado como separados ${ }^{25}$, de tal forma que, como o juízo instaura a cisão, o acesso ao ser puro e simples só pode se dar por uma intuição intelectual. Mais exatamente, para ele, a atividade judicativa do entendimento "pressupõe" um ser puro que o juízo cinde e identifica parcialmente; em outras palavras: sem um ser puro $e$ simples não haveria o que cindir e identificar (parcialmente) no juízo.

(...) juízo é separação original do objeto e do sujeito intimamente unidos na intuição intelectual, separação que torna possíveis sujeito e objeto (...). O conceito da divisão contém o conceito da relação recíproca do objeto e do sujeito e supõe necessariamente um todo do qual são partes ${ }^{26}$.

19 Em linhas gerais, como se vê, Hölderlin contrapõe o âmbito do juízo àquele do ser, na medida em que o primeiro nos coloca numa relação mediada com o último, e, ainda que 
reúna (nos termos de Fichte, sintetize) sujeito e predicado, só pode fazê-lo ao preço de instaurar uma "cisão" incontornável. Por outro lado, seu funcionamento necessariamente deve pressupor um "todo" que sua operação vem a cindir. Nessa medida, o acesso a isto que deve ser pressuposto para o funcionamento "lógico" do juízo só é possível por "intuição intelectual".

Com base nesta caracterização do juízo como a expressão, para recuperar mais uma vez a formulação aristotélica, de "algo como algo", Hölderlin dirige sua crítica a Fichte para mostrar o caráter paradoxal em apresentar o ser (Sein) pelo juízo (Urteil). Uma vez que a identidade apresentada no juízo só pode operar já na "cisão", mesmo o juízo que expressa a menor separação pensável entre o sujeito e o predicado, a expressão da autoconsciência, $E u$ sou $E u$, não pode apresentar a "unidade" do ser. Se, com isso, Hölderlin está ou não levando o idealismo para além de si mesmo, como quer Courtine, é outra questão $0^{27}$. De qualquer modo, sua crítica ao projeto filosófico de Fichte incide sobre o tema básico acerca do qual a Wissenschaftslehre acaba por ser um comentário: o juízo Eu sou eu não poderia apontar para a unidade, para o Sein, uma vez que, como juízo, ele expressa uma visão já cindida do ser.

21 Por conseguinte, o poeta é um dos primeiros, antes de Schelling e Hegel, a pensar o tema chave que está em debate na filosofia de Fichte - ainda que para criticá-la. Por um lado, como a natureza do juízo é a cisão e a síntese (parcial) das "partes", a identidade por ele apresentada já é uma mediação; por outro, o fundamento, o Grundsatz, deve ser algo anterior à predicação e à atividade judicativa - nessa medida, a proposição chave da filosofia de Fichte, Eu sou Eu, já pressupõe "algo": o ser puro e simples. A questão é que este "algo" não deve ser pensado como "algo" (i.e., já segundo os modos da predicação quantidade, qualidade, modalidade e relação), mas intuído intelectualmente como Sein - puro e simples ${ }^{28}$.

Em carta a Hegel de 25 janeiro de 1795, Hölderlin expressa sua crítica a Fichte de modo explícito e evidente:

Seu eu absoluto (=substância de Espinosa) contém toda a realidade... para esse eu absoluto não há objeto, pois, de outro modo, toda a realidade não estaria contida nele; mas uma consciência sem objeto não é concebível [ein Bewußtsein ohne Objekt ist aber nicht denkbar], e, se eu mesmo sou esse objeto, sou, enquanto tal, necessariamente limitado, ainda que apenas no tempo, portanto, não sou absoluto; no eu absoluto a consciência não é concebível; enquanto eu absoluto, não tenho consciência, e, uma vez que não tenho consciência, não sou nada (para mim); por conseguinte o eu absoluto não é nada para mim $^{29}$.

É conhecida a influência dos temas, senão dos conceitos, de Espinoza durante a primeira recepção da filosofia crítica, notadamente com os trabalhos de Jacobi ${ }^{30}$. Hölderlin, por seu turno, explicita o que acredita ser uma contradição no pensamento de Fichte: procurar pôr o Eu como absoluto. De resto, trata-se de uma crítica que será repetida por Hegel, mas a sutileza do poeta está em evidenciar a (pseudo?) contradição lógica e transcendental da tese de Fichte. $O$ "Eu", fosse realmente absoluto, não poderia ter consciência de si, visto que a consciência está fundamentalmente ligada à presença de um objeto, à posição, e à limitação de um objeto: uma consciência sem objeto não é concebível [ein Bewußtsein ohne Objekt ist aber nicht denkbar].

Em outras palavras, ou bem o "Eu" é absoluto - mas aí não seria um "eu", na medida em que não poderia ser consciente -; ou bem, o "Eu" é consciente, mas então não é absoluto porquanto "não há consciência sem objeto". No fundo, o poeta suábio retoma, em outros termos, a distinção que vimos mais acima entre a esfera do juízo - e da 
reflexão - e a esfera da intuição intelectual - único acesso ao absoluto; e isso para recusar à autoposição absoluta do eu o caráter de Grundsatz. Em suma, a oposição reflexiva pela qual Fichte pretende nos apresentar o Grund é incompatível com o absoluto e disso decorreria o erro de seu princípio ou, mais literalmente, de sua "proposição de fundo": Grundsatz. A questão bem compreendida, portanto, reside em saber qual é o direito em tomar o ser pelo acesso judicativo que temos a ele.

o ponto decisivo incide sobre a premissa do argumento de Hölderlin: só há consciência como consciência de objeto. Caso esta premissa seja verdadeira, então, talvez, realmente seja inconcebível tomar a consciência do "Eu" como instância absoluta. Mas, mesmo que isto seja verdadeiro, não se pode, de direito, assumir que, então, podemos falar no ser puro e simples como algo que esteja "antes" e "fora" do juízo.

Neste sentido, precisamos avaliar a posição de Fichte em duas etapas: primeiro em relação à tese de que a consciência só pode ser consciência como consciência de objeto; depois, em relação ao suposto direito em falar do ser fora da "posição" no juízo. Minha hipótese aqui é que a posição de Fichte em relação ao primeiro ponto decorre de sua tentativa de evitar um "salto mortal" antepredicativo no que concerne ao segundo tema.

Vejamos o primeiro dos aspectos da crítica de Hölderlin: "só há consciência como consciência de objeto". Deixarei de lado o tema da intersubjetividade uma vez que Hölderlin tem diante de si, quase que exclusivamente, a Grundlage 1794-5, embora isto não signifique que eu acredite numa "ruptura" entre o texto de 1794-5 e as exposições posteriores, notadamente, a exposição Nova Methodo na qual o tema da intersubjetividade é apresentado de modo bastante explítico ${ }^{31}$.

Quanto ao primeiro aspecto, então, vale dizer que o "Eu" deverá ser duplamente esvaziado de qualquer carga "ontológica": certamente ele não pode ser tomado em sentido "psicológico", mas também não deve ser visto como uma "substância" (ao contrário do que afirma Hölderlin, "Seu eu absoluto (=substância de Espinosa) contém toda a realidade..."). Não são poucas as passagens nas quais Fichte insiste no fato de que a Grundlage reflete sobre as "ações originárias" do eu, de forma que podemos inferir, sem grandes riscos, que aquilo que restava da ontologia clássica da substância foi dissolvido, pela Grundlage, na "atividade originária" - único reduto possível para o sentido do ser verdadeiramente compatível com a liberdade. Tudo se passa como se a antiga noção de substância (ousia), advinda da longa tradição aristotélica, tivesse se convertido, com a Wissenschaftslehre, num movimento de oscilação entre posição absoluta, oposição e limitação recíproca que a estrutura proposicional e judicativa tem por função apresentar (Darstellung).

De qualquer forma, como mostrou Günter Zöller, "estritamente falando, o eu não é um eu sem mais"; mais do que isso, a posição do não-eu não deve significar a "consciência de um objeto" 32 . Ou ainda, nos termos de Jean-François Courtine, "Hölderlin interpreta ontologicamente o eu fichtiano, sem levar em conta o fato de que a igualdade Ich = Ich é antes de tudo o resultado de uma Tathandlung" ${ }^{33}$. Sobre este ponto, podemos lembrar que na resenha ao Enesidemo de Schulze, Fichte já insistia que o erro básico deste último era exatamente o de tomar o juízo que enuncia a autoconsciência como um teorema dedutível de algum referente ou princípio (Grundsatz) mais elementar. Esta "referência", por assim dizer, só pode ser a atividade originária da consciência que é constitutiva do eu, da qual o juízo pretende ser a expressão mais adequada: 
Assim, a posição (Setzen) do Eu por si mesmo é a pura atividade (Tätigkeit) desse último. $\mathrm{O}$ Eu põe a si mesmo e é em virtude de seu ser puro. Ele é ao mesmo tempo o agente (Handelnde) e o produto da ação (Handlung); o ativo (Tätige) e aquilo que é trazido à existência (hervorgebracht) pela atividade (Tätigkeit); a ação (Handlung) e o feito (Tat) são um e o mesmo; por isso o Eu sou é a expressão de um estado-de-ação (Tathandlung); mas também do único possível, como deverá resultar da doutrina-daciência ${ }^{34}$. evidencia a espontaneidade como traço constitutivo do Eu e, no limite, a maneira pela qual Fichte vai tomar a liberdade como fundamento do sistema do saber. Em outras palavras, podemos dizer que, se há um sentido no ser, é porque ele se manifesta como liberdade. $O$ que temos aqui é a tradução do primado prático de Kant para os esquemas da Doutrina-da-ciência; e sem este primado prático, a tese de Fichte é absolutamente incompreensível. Suponho que foi exatamente a falta deste elemento que levou Hölderlin a ler o "Eu" de Fichte como correlato da substância de Espinosa. Nesse sentido, interpretou ontologicamente aquilo que não passa de um ponto de apoio indeterminado (ainda não fixado pelo entendimento e pelo juízo) e, por isto mesmo, fundamental para qualquer ontologia: a condição transcendental última que, segundo Fichte, teceria a trama categorial.

Hölderlin afirma, numa carta a seu irmão, de 13 de abril de 1795, que, para Fichte, há no homem uma aspiração (Streben) ao infinito, uma atividade (Täthigekeit) que faz com que todo limite (Schranke) permanente seja algo impossível, porquanto ele é uma atividade que tende a se tornar cada vez mais livre. Entretanto, esta atividade é limitada: infinita segundo sua pulsão (Trieb), tal atividade está num ser com consciência (o Eu), afinal a "limitação (Beschränkung) dessa atividade é necessária a um ser consciente" 35 . Novamente, Hölderlin insiste na idéia de que o objeto é condição limite para haver consciência, mas agora com uma inflexão prática bastante decisiva: "uma atividade (Täthigekeit) que faz com que todo limite (Schranke) permanente seja algo impossível". Não por acaso, dirá Courtine, é "sempre com Fichte que Hölderlin se insurge contra Fichte" ${ }^{36}$, de tal modo que utilizará a própria tese de Fichte acerca da limitação necessária à consciência para dela extrair a ideia de um ser designado antepredicativamente pela intuição intelectual, pressuposto do juízo, como assianalado anteriormente. Contra a doutrina de Fichte, que não deixa de ser uma inflexão do primado prático kantiano, de uma concordância (Übereinstimmung) prática apontada para o futuro, para um telos, Hölderlin sustenta a unidade (Einigkeit) prévia, como horizonte último da existência humana. Assim, podemos ler no Hyperion:

Aquele que não vive em igual e mútuo amor com o céu e a terra, aquele que não vive intimamente, nesse sentido, com o elemento em que se move, tampouco é por natureza assim unido a si mesmo ${ }^{37}$.

Agora podemos compreender o segundo tema apontado acima: aquele relativo ao suposto direito em falar do ser fora da "posição" no juízo. Ao que parece, as análises da Grundlage 1794-5 indicam que o juízo pode apenas apresentar (darstellung) uma imagem pálida do sistema do saber (que é um sistema da liberdade), por meio da síntese e antítese do juízo. Se os juízos obedecem ao "princípio de razão" e o juízo tético se apresenta como expressão da condição do próprio princípio de razão, isto não significa propriamente que a reflexão filosófica possa ultrapassar o campo judicativo. Como afirma Fichte:

O eu como sujeito filosofante é incontestavelmente apenas representativo; o eu como objeto do filosofar poderia perfeitamente ser ainda algo mais. O representar é 
a ação mais alta e absolutamente primeira do filósofo como tal; a ação

absolutamente primeira do espírito humano poderia perfeitamente ser outra. ${ }^{38}$ verdade que a reflexão filosófica não pode evadir do campo da representação. Nestes termos, mesmo que Fichte tenha assumido a possibilidade de uma intuição intelectual, ${ }^{39}$ ele nunca poderá conceder, como quer Hölderlin nos textos citados, que se trata da intuição de "algo", mas tão somente de um "ato originário". Ao final da parte teórica da Grundlage, Fichte insiste na correlação entre juízo e entendimento: "Se não há nada no entendimento, não há juízo; se não há juízo, não há nada no entendimento para o entendimento"; e, mais abaixo: "O pensável e a pensabilidade como tais são mero objeto do juízo. Apenas o julgado como pensável pode ser pensado como causa da intuição.” ${ }^{40}$

\section{IV}

À guisa de conclusão, gostaria de finalizar indicando uma possível transposição desta questão específica acerca do problema do juízo no início da Grundlage para os quadros mais gerais do pensamento de Fichte. Diante do velho dilema entre liberdade e necessidade, Fichte parece levar adiante a solução kantiana pensada a partir de um duplo "ponto de vista" (fenômenos e coisa-em-si). A Grundlage, ao que tudo indica, professa uma "dissolução" da clássica ideia de susbtância, assumindo a tarefa transcendental de fazer a "dedução genética" do que ocorre na consciência, inclusive da intuição. Neste sentido, ao fim e ao cabo, a "necessidade natural" não será outra coisa senão uma "fixação", pelo juízo, da oscilação da imaginação. Ou ainda, como afirma Fichte, é o entendimento que, por meio do juízo, "fixa" a intuição ${ }^{41}$ : "só no entendimento a realidade é [ainda que só pela imaginação]; ele é a faculdade do efetivo". 42

Nestes termos, o que pensar da vida política e da ação moral? Na tão citada carta a Baggesen, Fichte parece indicar uma direção precisa para esta questão:

Meu sistema é o primeiro sistema da liberdade. Assim como esta nação libertou a humanidade das cadeias materiais, meu sistema a liberta do julgo da coisa em si, das influências exteriores, e seus primeiros princípios fazem do homem um ser autônomo. A Doutrina-da-ciência nasceu durante os anos nos quais a nação francesa fez, sob o preço da força, triunfar a liberdade política (...). Enquanto eu escrevia uma obra sobre a Revolução, os primeiros pressentimentos de meu sistema surgiram em mim, como um tipo de recompensa ${ }^{43}$.

Talvez possamos dizer, pelo menos num sentido metafórico bem preciso, que a Wissenschafstelehre poderia ser vista como um comentário filosófico da Revolução Francesa. Mas, como tentei mostrar neste trabalho, uma "epistemologia" para a "Revolução" tem suas peripécias: apenas um ser diluído pelo movimento da atividade espontânea (originária e absoluta) pode ser complacente com a liberdade como fundamento do sistema do saber. Donde "natureza" como o ser puro e simples talvez seja o nome de uma "ilusão" romântica para quem já substituiu, como Hölderlin, a destinação do homem como liberdade pelo destino trágico de querer ser livre num mundo dominado pela ananké - como Édipo, Antígona ou Hypérion. Se assim for, de fato a arte só poderia ter um lugar subalterno nos quadros da Wissenschaftslehre e a "unidade" para as cisões kantianas, apenas indicada como horizonte e telos da vida política.

Revista de Estud(i)os sobre Fichte, 6 | 2013 


\section{NOTAS}

1. Cf. BWL, GA I/2, 150 y ss. (§ 8).

2. Citado acordo com a edição de von Hellingrafh (StA, ver Bibliografia) com a abreviatura UuS.

3. Contrariamente a Jere Paul Surber (2001), sustento que, na GWL Fichte não parece estabelecer uma distinção precisa entre juízo e proposição (Urteil e Satz), empregando estas expressões quase como sinônimas (para expressar o ato predicativo em geral); por isso mesmo, não creio que Fichte tenha invertido a relação entre estes termos tal como pensados por Kant.

4. GWL, GA I/2, 272; FSW I, 110-111 (o grifo é de Fichte).

5. Cf. Vuillemin 1962: I, 274 (nota).

6. GWL, GA I/2, 274; FSW I, 113.

7. Essa argumentação de Fichte sobre a noção de juízo é o ponto culminante da apresentação das três proposições fundamentais da exposição de 1794-5. Com as noções de limite e divisibilidade, a terceira proposição é estabelecida como limitação recíproca entre eu e não-eu e, a partir daí, os esclarecimentos sobre antítese e síntese se articulam para explicar como o funcionamento lógico do juízo depende da assunção do caráter absoluto do eu como síntese suprema. Aqui, apenas recortamos o aspecto "lógico" do argumento em vista da crítica de Hölderlin.

8. GWL, GA I/2, 274; FSW I:,114.

9. GWL, GA I/2, 279; FSW I, 119.

10. GWL, GA I/2, 275; FSW I, 115.

11. GWL, GA I/2, 270, FSW I, 108 (o grifo é de Fichte).

12. GWL, GA I/2, 273, FSW I, 112.

13. Para uma caracterização da GWL como uma investigação transcendental, cf. Steven Hoeltzel 2001: 40.

14. Cf. I. Kant, Logik, AA 09, 95, (§ 7 „Inhalt und Umfangder Begriffe“).

15. GWL, GA I/2, 274; FSW I, 113.

16. Que as leis lógicas estão pressupostas na exposição da GWL, Fichte o afirma explicitamente: “As leis da lógica geral (...) são pressupostas tacitamente" (GA I/2, 255; FSW I, 92). Sobre o fato de que a validade das leis lógicas deve ser condicionada pela Wissenschafstlehre, cf. BWL, GA I/2, FSW I, 68; Thomas-Fogiel 2004: 150-151.

17. GWL, GA I/2, 278; FSW I, 117-8: "Kant e seus seguidores chegaram, muito corretamente, a esses juízos infinitos, embora nenhum deles os tenha explicado de maneira clara e determinada". Fichte refere-se aqui ao problema, levantado por Kant na $\mathrm{KrV}$, da razão pela qual os "juízos infinitos" e "juízos afirmativos", identificados na lógica formal (ou geral), devem ser, do ponto de vista transcendental, diferenciados. Cf. KrV B 97-98.

18. GWL, GA I/2, 275; FSW I, 114.

19. Por uma "genetic deduction of what we find in our consciousness" (RAe, GA I/2, 55-56; FSW I, 15; 32) cf. Hohler 1982: 20.

20. GWL, GA I/2, 277; FSW I, 116.

21. O texto foi publicado pela primeira vez em 1961 por Friedrich Beissner com o título "Urteil und Sein", retirado de uma folha na guarda de um livro. Hölderlin. Cf. Hölderlins Sämtliche Werke, ed. Norbert von Hellingrafh, Berlim: Propyläen Verlag, Primeira Edição 1916 ("Urtheil und Seyn", in StA IV, p. 216-217); Oeuvres, Pléiade, pp.282-3. Cf. os artigos de Courtine 2006a, 2006b).

22. Na mesma direção, Dieter Henrich, 1997: 79 (nota 23).

23. Sobre este amplo assunto, cf., particularmente, a importante distinção entre sentença e proposição (logos apophantikos) no tratado Da Interpretação de Aristóteles, 16 b 5-17. De qualquer forma, para todos os efeitos, pôr "algo como algo" é peculiar ao ato predicativo. Cf. G. Zöller, 2001: 149. 
24. Sobre a complexa relação entre lógica e ontologia em Aristóteles, cf. P. Aubenque, 1962: 94-302.

25. A origem das noções de "separação" e "unificação" em Hölderlin não é exatamente lógica, ela remonta aos conceitos platônicos utilizados por Franz Hemsterhuis na interpretação da doutrina da Espinoza. Cf. D. Henrich: 1997: 76.

26. Hölderlin, "Urtheil und Seyn", in StA IV, p. 216; Pléiade, p. 282.

27. Courtine, 2006a: 44. Minhas análises não têm qualquer pretensão de estabelecer uma interpretação global das posições filosóficas de Hölderlin, mas tão somente apresentar uma leitura do referido fragmento "Juízo e Ser". Para uma visão geral das interpretações sobre Hölderlin, cf. D. Henrich, 1997: 74, que contrasta as visões de E. Cassirer, Kurt Hildebrandt, Johannes Hoffmeister, por exemplo. Sobre esta questão, por exemplo, Ryan Lawrence afirma que as versões do Hypérion, relativas ao período de Iena, documentam uma contínua aproximação a Fichte. Cf. R. Lawrence, 1965: 37.

28. D. Henrich, 1997: 75: "Being precedes every relation of the subject to an object, and can therefore never become an object of knowledge".

29. Hölderlin, StA VI, p.155; Oeuvres, Pléiade, pp. 340-341. O grifo é meu. W. Binder (StA, VI, p. 216-7) propõe que se leia no final, für sich ao invés de für mich, como um equívoco de escrita. Não me parece ser este o caso, pois creio que o tom provocativo é muito mais proeminente na forma em que o fragmento está literalmente escrito, i.e., für mich.

30. Cf. Dieter Henrich, 1997: 29.

31. Cf. J.G.M. Cunha, 2011: 06-27. Para um balanço e um posicionamento bastante acurados, cf. I. Radrizzani, 1993: 19-47.

32. G. Zöller, 2001: 138-152.

33. Courtine 2006b: 75.

34. GWL, GA I/2, 259; FSW I, 96.

35. Hölderlin: 1967, 346-349.

36. Courtine 2006b: 82 . De fato, podemos ler em Fichte, com todas as letras, o que pretende sustentar Hölderlin: "O Eu é infinito apenas em seu esforço. A finitude já é interior ao conceito. Não fosse o esforço, ele não seria nada”. (GA, I/2, 404; FSW I, 270)

37. UuS, StA IV, 490.

38. BWL, GA I/2, 149; FSW I, 80.

39. ZE, GA I/4, 276; FSW I, 528.

40. GWL, GA I/2, 381; FSW I, 242-243.

41. GWL, GA I/2, 381; FSW I/ 242.

42. GWL, GA I/2, 374; FSW I/ 234.

43. Carta a Baggessen, abril de 1795, GA III/2, 298.

\section{RESUMOS}

The theme of "unity" seems to have been one of the central keys both to the convergence and complete rupture between Romanticism and Fichte's philosophy. In this paper, I will explore one of the aspects of this subject from a well-defined and specific perspective, which requires the reconstruction (1) in its more general outlines, of the conception of judgment carried out by the Grundlage of 1794-5; and (2) of the critique addressed to Fichte's project that is outlined in a 
fragment, known as "Judgment and Being", written by Hölderlin - who, although not exactly a "Romantic", takes a position, from my point of view, quite emblematic in regard to the dialog Fichte establishes with the Romantics strictu sensu.

ÍNDICE

Keywords: Hölderlin, theory of judgements, doctrine of science

\section{AUTOR}

JOÃO GERALDO MARTINS DA CUNHA

Universidade Federal de Lavras - MG / Brasil 